\title{
Accumulation and dynamics of manganese in raspberry
}

\author{
Senad MURTIĆ ${ }^{1,2}$, Emir ŠAHINOVIĆ ${ }^{1}$, Hamdija ČIVIĆ ${ }^{3}$, Emina SIJAHOVIĆ ${ }^{3}$
}

Received February 25, 2019; accepted April 23, 2019.

Delo je prispelo 25. februarja 2019, sprejeto 23. aprila 2019.

\section{Accumulation and dynamics of manganese in raspberry}

Abstract: The aim of this study was to evaluate the dynamics of $\mathrm{Mn}$ in 'soil - raspberry' system on the area around the manganese ore deposits Radostovo in Bužim municipality. Atomic absorption spectroscopy was used to determine the concentration of $\mathrm{Mn}$ in soil and plant samples. $\mathrm{Fe}, \mathrm{Zn}$ and $\mathrm{Cu}$ concentration in soil and raspberry plants was also subject of analysis, since these elements have antagonistic relationship with $\mathrm{Mn}$ in soils. The concentration of available $\mathrm{Mn}$ in soils was low, although the total $\mathrm{Mn}$ in the same soils exceeded the Mn toxic values noted in the scientific literature. The chemical and physical properties of the examined soils characterized by a relatively high $\mathrm{pH}$ value and good ability to store root-zone air certainly contributed to the decreasing release of available $\mathrm{Mn}^{2+}$ from manganese oxides in soils as well as $\mathrm{Mn}^{2+}$ oxidation to insoluble $\mathrm{Mn}^{3+}$ or $\mathrm{Mn}^{4+}$ ions, resulting in low uptake of $\mathrm{Mn}$ by plant roots. The results of study also showed that the absorbed Mn mostly accumulates in leaves and roots of raspberry, and much less in the stem and fruits. That rule in Mn distribution within raspberry plant is in fact identical to all food crops.

Key words: availability; nutrients; Mn; plant; soil; uptake

\section{Kopičenje in dinamika mangana v malinjaku}

Izvleček: Namen raziskave je bil ovrednotiti dinamiko Mn v sistemu tla-malinjak na območju $\mathrm{z}$ manganovo rudo Radostovo, v občini Bužim. Za določanje koncentracije Mn v vzorcih tal in rastlin je bila uporabljena atomska absorpcijska spektroskopija. Analizirane so bile tudi vsebnosti Fe, $\mathrm{Zn}$ in $\mathrm{Cu} v$ tleh in v malinjaku, ker imajo ti elementi antagonistično razmerje do Mn v tleh. Koncentracije razpložljivega Mn v tleh so bile majhne, čeprav so vsebnosti celokupnega $\mathrm{Mn} v$ istih tleh presegale njegove toksične vrednosti, navedene $\mathrm{v}$ znanstveni literaturi. Analizirana tla so imela relativno visok $\mathrm{pH}$ in dobro prezračenost, kar je gotovo prispevalo $\mathrm{k}$ zmanjšanju razpoložljivega $\mathrm{Mn}^{2+}$ iz manganovih oksidov v tleh kot tudi k oksidaciji $\mathrm{Mn}^{2+} \mathrm{v}$ netopni $\mathrm{Mn}^{3+}$ ali $\mathrm{Mn}^{4+}$, kar je povzročilo majhen privzem Mn v korenine. Rezultati te raziskave so tudi pokazali, da se večina absorbiranega Mn kopiči v listih in koreninah malinjaka in veliko manj v steblu in plodovih. To pravilo v porazdelitvi Mn v malinjaku je dejansko enako za vse kmetijske rastline.

Ključne besede: razpoložljivost; hranila; Mn; rastlina; tla; privzem

1 University of Sarajevo, Faculty of Agriculture and Food Sciences, Department of Plant Physiology, Sarajevo, Bosnia and Herzegovina

2 Corresponding author, e-mail: murticsenad@hotmail.com

3 University of Sarajevo, Faculty of Agriculture and Food Sciences, Department of Plant Nutrition, Sarajevo, Bosnia and Herzegovina 


\section{INTRODUCTION}

Manganese $(\mathrm{Mn})$ is a mineral element that is both essential and potentially toxic for plant. It is essential for many plant functions, particularly for antioxidant defense system in plants as an enzyme antioxidant-cofactor (Millaleo et al., 2010). Furthermore, Mn participates in the structure of photosynthetic proteins and enzymes playing an important role in water-splitting system of photosystem II, which provides the necessary electrons for photosynthesis (Mousavi et al., 2011). In addition, Mn activates many enzymes that catalyzes decarboxylation, fatty acids synthesis or hydrolysis (Scăețeanu et al., 2013). Nevertheless, an excess of Mn is toxic for plants. Kastori et al. (1997) reported that Mn concentration above $150 \mathrm{mg} \mathrm{kg}^{-1}$ in plant tissue can negatively affect life processes in plant whereas the concentration of 400 $\mathrm{mg} \mathrm{kg}{ }^{-1}$ dry matter is toxic. Excess of $\mathrm{Mn}$ in plants resulting in a reduction of biomass and photosynthesis, disturbances in absorption, translocation and utilization of mineral elements $\mathrm{Ca}, \mathrm{Mg}, \mathrm{Fe}, \mathrm{P}$ and biochemical disorders such as oxidative stress (Lei et al, 2007).

$\mathrm{Mn}$ is not encountered as free element in the environment. It is found combined with other elements such as oxygen, carbon, silicon, Sulphur, chloride, and iron in various $\mathrm{Mn}$-compounds, the most widespread one being pyrolusite $\left(\mathrm{MnO}_{2}\right)$ followed by rhodocrosite $\left(\mathrm{MnCO}_{3}\right)$, knebelite $\left((\mathrm{MnFe})_{2} \mathrm{SiO}_{4}\right)$, hausmannite $\left(\mathrm{Mn}_{3} \mathrm{O}_{4}\right)$, manganite $\left(\mathrm{Mn}_{2} \mathrm{O}_{3} \cdot \mathrm{H}_{2} \mathrm{O}\right)$ etc. (Wang et al., 2017). In soil Mn occurs in many oxidation states (from -3 up to +7 ) with widely divergent solubilities. Divalent manganese $\left(\mathrm{Mn}^{2+}\right)$ is the most soluble forms of $\mathrm{Mn}$ in soil and therefore the most available Mn form for plants, whereas the solubility of $\mathrm{Mn}^{3+}$ and $\mathrm{Mn}^{4+}$ are very low because these ions form insoluble hydrous oxides (Li et al., 1999).

The occurrence of $\mathrm{Mn}$ in various forms in soil depends on different physical, chemical and microbiological processes of which $\mathrm{pH}$ and redox conditions are more important (Husson, 2013). In acid soils at low $\mathrm{pH}(<5.5), \mathrm{Mn}$ oxides are solubilized and release $\mathrm{Mn}^{2+}$ in soil solution, while in higher soil $\mathrm{pH}$ (up to $\mathrm{pH} 8$ ), plant available $\mathrm{Mn}^{2+}$ is oxidized to insoluble $\mathrm{Mn}^{3+}$ or $\mathrm{Mn}^{4+}$ ions. Organic matter content and microbial activity also plays a very important rule in the solubility of $\mathrm{Mn}$ in soil. Bradl (2004) reported that the increase of organic matter in soil is correlated with the decrease of the available $\mathrm{Mn}^{2+}$ forms due to the formation of $\mathrm{Mn}$ complexes. Furthermore, higher organic matter also intensifies microbiological activity, which can further decrease the availability of Mn. Namely, some microbes can catalyze the oxidation of $\mathrm{Mn}^{2+}$ more fast than abiotic oxidation, resulting in increased insoluble $\mathrm{Mn}$ forms in soil. The availability of $\mathrm{Mn}$ in soil also depends on other soil properties such as soil moisture and aeration, and antagonistic interaction among $\mathrm{Mn}$ and some other elements in soil such as $\mathrm{Cu}, \mathrm{Zn}$ and Fe (Sparrow and Uren, 2014).

Furthermore, the uptake of $\mathrm{Mn}^{2+}$ from soil solution by plants root, is also dependent on the genetic predisposition of the plants (Dučić and Polle, 2005). There are plant species considered more sensitive to excess $\mathrm{Mn}$ in soil: beans, lettuce, cabbage, soybean, cauliflower, potato; cucumber and watermelon are moderate; while field corn, rice, sugarcane, and tomato are tolerant on excess $\mathrm{Mn}$ in soils (Horst, 1988). According to available literature data, degree of tolerance of raspberry on excess $\mathrm{Mn}$ in soil has yet to be tested.

In the area of Bužim municipality, in the northwestern Bosnia, there are several deposits of $\mathrm{Mn}$ ore, so it is assumed that the soils in their vicinity contain high Mn levels. Also, in this area the raspberry cultivation is highly represented, and therefore this area is very suitable for testing the degree of tolerance of raspberry to excess $\mathrm{Mn}$ in soil.

The main purpose of this research was to evaluate the dynamics of Mn in system 'soil - raspberry' on the area near the manganese ore deposits Radostovo in Bužim municipality.

\section{MATERIALS AND METHODS}

\subsection{STUDY AREA}

The experiment was carried out during 2018 on the soils near Mn ore deposits Radostovo, located about $1 \mathrm{~km}$ northeast of the Bužim town area $\left(45^{\circ} 3^{\prime} 17^{\prime \prime}\right.$ $\mathrm{N}, 16^{\circ} 1^{\prime} 55^{\prime \prime} \mathrm{E}$ ). The geological structure of this area is mainly composed by limestones and dolomites and volcanic rocks. The Mn ore deposit occurs where the volcanogenic-sedimentary series overlie dolomites and dolomitic limestone. The deposit is dark-red in color, due to the high Mn concentration (Redžić et al., 2014). The climate in Bužim municipality is classified as Cfb by the Köppen-Geiger system. The average annual temperature is $10.7^{\circ} \mathrm{C}$ and the average annual rainfall is $1061 \mathrm{~mm}$. The study area included three soil plots in the immediate vicinity of the $\mathrm{Mn}$ ore deposits Radostovo. All selected soil plots are used for raspberry production and size of each plot is approximately $500 \mathrm{~m}^{2}$. The natural profile of all examined soil may be designated as A$\mathrm{B}(\mathrm{rz})-\mathrm{R}$. The color of A (humus accumulative horizon) in soils was dark-brown and its depth ranged from 10 to $15 \mathrm{~cm}$. B (rz) (cambic horizon) was characterized by moderately fine texture and good water-holding capac- 
ity. The color of this horizon was dark-red, and depth ranged from 30 to $50 \mathrm{~cm}$. Accordingly, these soils are classified as calcic cambisols (FAO, 2014).

\subsection{SOIL SAMPLING}

The soil samples from each experimental plot were collected at February 2018 at a depth of $0-30 \mathrm{~cm}$ using a soil sampler probe. On each plot were collected individual soil samples from five spots (north, south, east, west and center of the plot), and then they were thoroughly mixed to obtain an average sample. After collection, soil samples were transferred to the laboratory of Faculty of Agriculture and Food Sciences University of Sarajevo. Soil samples were cleared of impurities, airdried at room temperature, crushed and grinded using soil mortar and pestle, sifted through sieves (2 and 1 $\mathrm{mm}$ hole diameter) and then stored until the moment of laboratory analysis.

\subsection{SOIL CHEMICAL ANALYSIS}

The chemical analysis of the average soil sample included the determination of the following parameters: soil acidity, humus content, content of available forms of phosphorus $\left(\mathrm{P}_{2} \mathrm{O}_{5}\right)$ and potassium $\left(\mathrm{K}_{2} \mathrm{O}\right)$, as well as the most important parameter: the concentration of total and available forms of $\mathrm{Mn}$ in soil. The concentration of total and available forms of $\mathrm{Fe}, \mathrm{Zn}$ and $\mathrm{Cu}$ in soil sample was also subject of this research, as it is known that these elements have the antagonistic relationship with Mn which can greatly affect the dynamics of manganese in the soil plant system.

Soil $\mathrm{pH}$ was determined in $\mathrm{H}_{2} \mathrm{O}$ and $1 \mathrm{M} \mathrm{KCl}$ by pH meter according to ISO 10390 method (ISO, 2005), humus content by oxidation with potassium dichromate in the presence of sulphuric acid according to ISO 14235 method (ISO, 1998), content of available forms of phosphorus $\left(\mathrm{P}_{2} \mathrm{O}_{5}\right)$ and potassium $\left(\mathrm{K}_{2} \mathrm{O}\right)$ were determined by AL-method based on extraction with ammonium lactate-acetic acid (Egnér et al., 1960).

Analysis of total and available forms of $\mathrm{Mn}, \mathrm{Fe}$, $\mathrm{Zn}, \mathrm{Cu}$ and in soils were performed using atomic absorption spectrophotometry on Shimadzu AA 7000 according to the instructions specified in the ISO 11047 method (ISO, 1998).

Previous extraction of total forms of $\mathrm{Mn}, \mathrm{Fe}, \mathrm{Cu}$, $\mathrm{Zn}$ from the soil was performed using aqua regia solution (ISO, 1995), while the extraction of available forms of these elements was performed using the EDTA solution (ethylenediaminetetraacetic acid).
Aqua regia extraction was prepared as follows: $3 \mathrm{~g}$ of air-dried soil sample was transferred into $250 \mathrm{ml}$ round bottom flask. Then, $28 \mathrm{ml}$ of aqua regia (mixture of $\mathrm{HNO}_{3}$ and $\mathrm{HCl}$ in 1: 3 ratio) was added. The flask was covered with a watch glass and allowed to stand 16 hours (overnight) in the digester. The solution was heated on hot plate under reflux and the temperature and digestion time was $270{ }^{\circ} \mathrm{C}$ and $2 \mathrm{hr}$. Thereafter, the flask allowed to cool to room temperature for $10 \mathrm{~min}$ and to this cooled solution was added $15 \mathrm{ml}$ of distilled water to dilute the acid concentration. Then, the solution was filtered through quantitative filter paper into $100 \mathrm{ml}$ flask and diluted to the mark with deionized water (ISO, 1995).

Extraction of available forms of Mn from the soil was performed as follows: $10 \mathrm{~g}$ of air-dried soils was transferred into $100 \mathrm{ml}$ plastic bottle, then $20 \mathrm{ml}$ EDTA solution $\left(0.01 \mathrm{~mol} \mathrm{dm} \mathrm{dm}^{-3}\right.$ ethylenediaminetetraacetic acid (EDTA) and $1 \mathrm{~mol} \mathrm{dm}{ }^{-3}\left(\mathrm{NH}_{4}\right)_{2} \mathrm{CO}_{3}$, adjusted to $\mathrm{pH}$ 8.6) was added. The solution in bottle was shaken $30 \mathrm{~min}$ in an orbital shaker at $180 \mathrm{rpm}$. Thereafter the solution was filtered through quantitative filter paper into $25 \mathrm{ml}$ flask and diluted to the mark with deionized water (Trierweler and Lindsay, 1969).

\subsection{PLANT SAMPLING}

Ten fresh raspberry plants (Rubus idaeus L. cultivar 'Willamette') from each examined soil plot were collected very carefully in August 2018 at the stage of commercial maturity, then placed in clean paper bags and transported to the laboratory.

Leaves, root, and fruits of each plant were separated, dried in oven at $40{ }^{\circ} \mathrm{C}$ until constant mass, grinded and then stored in little paper bags until analyzed. Three replicate measurements were performed to obtain mean and standard deviation of $\mathrm{Mn}, \mathrm{Fe}, \mathrm{Zn}$ and $\mathrm{Cu}$ concentration for each plant part.

\subsection{PLANT ANALYSIS}

Extraction of $\mathrm{Mn}, \mathrm{Fe}, \mathrm{Zn}$ and $\mathrm{Cu}$ from plant samples was performed as follows: $1 \mathrm{~g}$ of air-dried and grinded plant sample was placed in $100 \mathrm{ml}$ round bottom flask. Then, $7 \mathrm{ml}$ of a mixture of $\mathrm{HNO}_{3}$ and $\mathrm{H}_{2} \mathrm{SO}_{4}$ with a volume ratio of 2.5: $1(\mathrm{v} / \mathrm{v})$ was added. The flask was left for a few hours at room temperature, and then gently heated on a hot plate for thirty minutes. The solution was cooled to room temperature, filtered through quantitative filter paper into $50 \mathrm{ml}$ flask and made up to the mark with deionized water (Lisjak et al., 2009). 
The concentration of $\mathrm{Mn}, \mathrm{Fe}, \mathrm{Zn}$ and $\mathrm{Cu}$ in the plant samples was also determined using atomic absorption spectrophotometry.

\subsection{STATISTICAL ANALYSIS}

All experimental measurements were performed in triplicate and the results were presented as mean \pm standard deviation. Statistical analyses were carried out by one-way ANOVA and LSD comparison post hoc tests. Significant differences were accepted at $p<0.05$. The analyses were performed using Microsoft Excel software.

\section{RESULTS}

\subsection{CHEMICAL PROPERTIES OF THE EXAM- INED SOILS}

Selected chemical properties of the soil plots near the manganese ore deposits Radostovo are presented in Table 1.

Results of soil chemical analysis showed that soil 1 had a neutral reaction with moderate level of organic matter, while the soil plot 2 and 3 had a slightly acid reaction and a low level of organic matter. All examined soil had a low content of available forms of phosphorus $\left(\mathrm{P}_{2} \mathrm{O}_{5}\right)$ and moderate level of available forms of potas$\operatorname{sium}\left(\mathrm{K}_{2} \mathrm{O}\right)$.

\subsection{MN, FE, ZN AND CU CONCENTRATIONS IN SOIL SAMPLES}

Determined values of total and available forms of $\mathrm{Mn}, \mathrm{Fe}, \mathrm{Zn}$, and $\mathrm{Cu}$ in soils are listed in Table 2.

The concentration of total Mn in soils greatly exceeded the permissible limit value for agricultural soils of $850 \mathrm{mg} \mathrm{kg}^{-1}$ noted by Pais and Jones (1997) or $1000 \mathrm{mg} \mathrm{kg}^{-1}$ noted by Vukadinović and Vukadinović (2001), and that result was expected since the examined soil plots were located near the manganese ore deposits. Fe concentration in analyzed soils was noticeably higher than the average value of Fe in soil (0.6\%) reported by Kabata-Pendias and Pendias (2001). Limit value of Fe in soils is not in the legislative rules or the main topic of discussion among scientists, because $\mathrm{Fe}$ is not direct contaminant of soil. $\mathrm{Zn}$ and $\mathrm{Cu}$ concentration in the examined soil samples did not exceed the maximum permissible value prescribed by the legislation in Bosnia and Herzegovina (Official Gazette of $\mathrm{FBiH}, 2009$ ), indicating that the examined soils are not polluted by these elements.

The available $\mathrm{Mn}$ concentration in soils ranged between 13.4 and $14.7 \mathrm{mg} \mathrm{kg}^{-1}$ dry mass, and these amounts were relatively low compared with toxic level of $200 \mathrm{mg} \mathrm{kg}^{-1}$ reported by Lindsay and Cox (1985). In the soil samples extracted with EDTA solution, the concentration of Fe ranged from 11.99 to $19.1 \mathrm{mg} \mathrm{kg}^{-1}$ which was about $0.16 \%$ of total Fe in soil. This data supports the hypothesis that only small fraction of Fe in the soil occurs in bioavailable forms (Violante et al., 2010). The

Table 1: Chemical properties of the examined soils

\begin{tabular}{|c|c|c|c|c|}
\hline Parameter & measured value & soil plot 1 & soil plot 2 & soil plot 3 \\
\hline $\mathrm{pH} \mathrm{H}_{2} \mathrm{O}$ & $\mathrm{pH}$ unit & 7.3 & 6.8 & 6.6 \\
\hline $\mathrm{pH} \mathrm{KCl}$ & $\mathrm{pH}$ unit & 6.6 & 5.7 & 5.4 \\
\hline humus & $\%$ & 2.67 & 1.97 & 1.61 \\
\hline $\mathrm{P}_{2} \mathrm{O}_{5}$ & $\mathrm{mg} 100 \mathrm{~g}^{-1}$ & 0.71 & 0.77 & 0.66 \\
\hline $\mathrm{K}_{2} \mathrm{O}$ & $\operatorname{mg~} 100 \mathrm{~g}^{-1}$ & 23.1 & 23.2 & 18.5 \\
\hline
\end{tabular}

Table 2: Concentration of total and available forms of $\mathrm{Mn}, \mathrm{Fe}, \mathrm{Zn}$, and $\mathrm{Cu}$ in soils

\begin{tabular}{lllllllll}
\hline \multirow{2}{*}{ Soil plot } & \multicolumn{2}{l}{ Concentration $(\mathrm{mg} \mathrm{kg}$ dry mass $)$} & & & & \\
\cline { 2 - 9 } & $\mathrm{Mn}^{*}$ & $\mathrm{Mn}^{* *}$ & $\mathrm{Fe}^{*}$ & $\mathrm{Fe}^{* *}$ & $\mathrm{Zn}^{*}$ & $\mathrm{Zn}^{* *}$ & $\mathrm{Cu}^{*}$ & $\mathrm{Cu}^{* *}$ \\
\hline 1 & 2034.8 & 14.7 & 10529.2 & 11.99 & 51.1 & 0.88 & 28.8 & 2.31 \\
2 & 1849.9 & 13.4 & 10973.1 & 12.59 & 51.3 & 0.75 & 31.8 & 2.21 \\
3 & 2228.2 & 14.4 & 11421.9 & 19.1 & 45.6 & 0.88 & 25.2 & 1.97 \\
Permissible value & 1000 & - & - & - & $200^{2}$ & - & $80^{2}$ & - \\
\hline
\end{tabular}

"total forms; " available forms

${ }^{2}$ Permissible value prescribed by legislation in $\mathrm{BIH}$ 
availability ratio (percentage available fraction in relation to total concentration) for $\mathrm{Cu}$ and $\mathrm{Zn}$ was much higher and it ranged from $6.94 \%$ to $7.81 \%$ for $\mathrm{Cu}$ and from $1.46 \%$ to $1.93 \%$ for $\mathrm{Zn}$.

\subsection{MN, FE, ZN AND CU CONCENTRATIONS IN PLANT SAMPLES}

Concentration of $\mathrm{Mn}, \mathrm{Fe}, \mathrm{Zn}$ and $\mathrm{Cu}$ in different parts of raspberry plants that have been grown in soil plots near the Mn ore deposits Radostovo is given in Table 3,4 and 5 .

The results have shown that the concentration of $\mathrm{Fe}, \mathrm{Zn}$ and $\mathrm{Cu}$ in the examined plant parts was relatively low in comparison with the permissible limits of heavy metals in food crops reported by FAO/WHO (2001). Accordingly, the maximum permissible value for $\mathrm{Fe}, \mathrm{Zn}$ and $\mathrm{Cu}$ is $425 \mathrm{mg} \mathrm{kg}^{-1}, 99.4 \mathrm{mg} \mathrm{kg}^{-1}$, and $\mathrm{Cu} 73.3 \mathrm{mg} \mathrm{kg}^{-1}$, respectively. Mn concentration in the parts of raspberry plants was also low and not even close to the toxic value for $\mathrm{Mn}$ in the plant $\left(400 \mathrm{mg} \mathrm{kg}^{-1}\right.$ ) reported by Kastori et al. (1997). These findings were unexpected given the fact that the present study was conducted on soils containing high Mn concentration.

\section{DISCUSSION}

Total Mn and Fe concentration in soils differs considerably, primarily depending on the composition of the parent rock materials and the degree of weathering. Emsley (2001) reported that soil contains between 7 and $9000 \mathrm{mg} \mathrm{kg}^{-1}$ of $\mathrm{Mn}$ with an average of $440 \mathrm{mg} \mathrm{kg}^{-1}$, while the average Fe concentration in soils is about $0.6 \%$ (Kabata-Pendias and Pendias, 1999).

$\mathrm{Mn}$ and Fe concentration in all examined soil contain much more $\mathrm{Mn}$ and $\mathrm{Fe}$ in relation to the average values for $\mathrm{Mn}$ and $\mathrm{Fe}$ in soils, indicating that the soils in the vicinity of the Mn ore deposits Radostovo have the potential to contaminate the agricultural crops by $\mathrm{Mn}$ and Fe. It is assumed that the parent material of these soils is characterized by Fe and Mn oxide minerals. This observation consistent with the result reported by Redžić et al. (2014) and Grigorova (2011) who stated the high presence of $\mathrm{Mn}$ and Fe oxide minerals such as romanechite, vernadite, pyrolusite, hematite and pyrite in the complex formations of the parent material in this area.

Although the total Mn concentration in soils was high, the concentration of available forms of $\mathrm{Mn}$ in the same soils was relatively low considering that values between 140 and $200 \mathrm{mg} \mathrm{kg}^{-1}$ regarded as excess (Lindsay

Table 3: Concentration of heavy metals in raspberry plants from soil plot 1

\begin{tabular}{lllll}
\hline \multirow{2}{*}{ Part of the plant } & \multicolumn{4}{l}{ Soil plot 1: Concentration $\left(\mathrm{mg} \mathrm{kg}^{-1}\right.$ dry mass $)$} \\
\cline { 2 - 5 } root & Mn & Fe & Zn & Cu \\
stem & $56.89 \pm 6.03^{\mathrm{b}}$ & $219.39 \pm 30.92^{\mathrm{a}}$ & $36.82 \pm 11.69^{\mathrm{a}}$ & $11.96 \pm 1.78^{\mathrm{a}}$ \\
leaves & $16.69 \pm 3.18^{\mathrm{c}}$ & $52.59 \pm 6.68^{\mathrm{c}}$ & $17.02 \pm 3.88^{\mathrm{b}}$ & $2.62 \pm 1.75^{\mathrm{b}}$ \\
fruit & $70.24 \pm 8.88^{\mathrm{a}}$ & $110.62 \pm 15.64^{\mathrm{b}}$ & $22.61 \pm 4.75^{\mathrm{b}}$ & $4.37 \pm 3.06^{\mathrm{b}}$ \\
LSD $_{0.05}$ & $12.52 \pm 2.93^{\mathrm{c}}$ & $66.32 \pm 12.51^{\mathrm{c}}$ & $22.93 \pm 12.78^{\mathrm{b}}$ & $4.11 \pm 2.91^{\mathrm{b}}$ \\
\hline
\end{tabular}

Values expressed as main \pm standard deviation.

Different letters in each column represent significant difference among variants at 0.05 level of probability

Table 4: Concentration of heavy metals in raspberry plants from soil plot 2

\begin{tabular}{lllll}
\hline \multirow{2}{*}{ Part of the plant } & \multicolumn{4}{l}{ Soil plot 2: Concentration $\left(\mathrm{mg} \mathrm{kg}^{-1}\right.$ dry mass $)$} \\
\cline { 2 - 5 } Mn & $70.77 \pm 8.78^{\mathrm{b}}$ & $\mathrm{Fe}$ & $\mathrm{Zn}$ & $\mathrm{Cu}$ \\
\hline root & $30.71 \pm 13.6^{\mathrm{c}}$ & $52.29 \pm 13.56^{\mathrm{c}}$ & $71.54 \pm 15.65^{\mathrm{a}}$ & $13.22 \pm 4.03^{\mathrm{a}}$ \\
stem & $111.45 \pm 18.57^{\mathrm{a}}$ & $80.29 \pm 16.75^{\mathrm{b}}$ & $19.23 \pm 6.89^{\mathrm{b}}$ & $4.26 \pm 2.02^{\mathrm{b}}$ \\
leaves & $21.23 \pm 8.89^{\mathrm{c}}$ & $67.45 \pm 14.87^{\mathrm{bc}}$ & $18.06 \pm 7.79^{\mathrm{b}}$ & $4.27 \pm 2.72^{\mathrm{b}}$ \\
fruit & 12.95 & 22.69 & $25.34 \pm 6.3^{\mathrm{b}}$ & $4.73 \pm 1.23^{\mathrm{b}}$ \\
LSD $_{0.05}$ & & & 10.82 & 2.61 \\
\hline
\end{tabular}

Values expressed as main \pm standard deviation.

Different letters in each column represent significant difference among variants at 0.05 level of probability. 
Table 5: Concentration of heavy metals in raspberry plants from soil plot 3

\begin{tabular}{|c|c|c|c|c|}
\hline \multirow[b]{2}{*}{ Part of the plant } & \multicolumn{4}{|c|}{ Soil plot 3: Concentration (mg kg-1 dry mass) } \\
\hline & $\mathrm{Mn}$ & $\mathrm{Fe}$ & $\mathrm{Zn}$ & $\mathrm{Cu}$ \\
\hline root & $59.91 \pm 11.28^{\mathrm{ab}}$ & $209.07 \pm 22.98^{\mathrm{a}}$ & $33.15 \pm 5.12^{\mathrm{a}}$ & $15.57 \pm 5.56^{\mathrm{a}}$ \\
\hline stem & $16.63 \pm 6.82^{c}$ & $63.32 \pm 15.52^{c}$ & $21.18 \pm 8.41^{b}$ & $2.79 \pm 3.45^{\mathrm{b}}$ \\
\hline leaves & $67.11 \pm 19.8^{\mathrm{a}}$ & $90.85 \pm 14.58^{\mathrm{b}}$ & $21.03 \pm 4.8^{\mathrm{b}}$ & $2.78 \pm 2.33^{\mathrm{b}}$ \\
\hline fruit & $14.76 \pm 5.19^{c}$ & $73.11 \pm 11.94^{c}$ & $21.63 \pm 6.3^{\mathrm{b}}$ & $4.61 \pm 2.71^{\mathrm{b}}$ \\
\hline$\underline{\mathrm{LSD}}_{0.05}$ & 11,32 & 16.81 & 6.43 & 3.81 \\
\hline
\end{tabular}

Values expressed as main \pm standard deviation.

Different letters in each column represent significant difference among variants at 0.05 level of probability.

and Norvell, 1978; Silanpaa, 1982; Esu, 1991). Podlesakova et al. (2002) noted that $100 \mathrm{mg} \mathrm{kg}^{-1}$ of available $\mathrm{Mn}$ in soil is also potentially harmful to food crops. In our study, determined values of available forms of Mn were not even close to above-mentioned critical value.

The concentration of available forms of Fe was also low, about $0.16 \%$ of total Fe concentration in soil. These data indicate that the total concentration of elements in soils does not provide reliable information on their mobility, availability and consequently toxicity (Nunes et al., 2014). One of the main reasons for the low $\mathrm{Mn}$ and $\mathrm{Fe}$ availability in the examined soils are closely related to the soil redox potential and $\mathrm{pH}$ value (Dufey et al., 2009). It is well known that the release of most available $\mathrm{Mn}$ $\left(\mathrm{Mn}^{2+}\right)$ and $\mathrm{Fe}\left(\mathrm{Fe}^{2+}\right)$ forms from $\mathrm{Mn}$ and $\mathrm{Fe}$ oxide minerals is only possible in acid soils and under anaerobic conditions resulting from waterlogging or very high organic matter content in soils (Rengel, 2015). Namely, when oxygen is depleted from the soil solution, the divalent state of $\mathrm{Mn}$ and Fe can be oxidized to the trivalent state, where it may form oxides or hydroxide precipitates and become unavailable to plants (Khabaz-Saberi and Rengel, 2010). It is assumed that the higher $\mathrm{pH}$ value $\left(>6.3\right.$ in $\left.\mathrm{H}_{2} \mathrm{O}\right)$ of examined soils contributed to the lower Fe and Mn solubility, and thus the availability of these elements in soils.

The availability of $\mathrm{Mn}, \mathrm{Fe}$ and generally nutrients in soils is also dependent on plant exudates from roots, and the interactions of plant roots with microorganisms. Plants have potential to exude a variety of organic compounds (phenolics, carbohydrates, amino acids, enzymes, etc.) and inorganic ions (protons, phosphate, etc.) to change rhizosphere chemistry and biology and thus increase or decrease nutrient availability (Marschner et al., 2011). Some of these exudates can promote the activity of Mn-reducing microorganisms in the rhizosphere, increasing Mn availability (Guest et al., 2002). Contrarily, the higher presence of microorganisms that oxidize $\mathrm{Mn}$ in soil decreases its availability to plants (Porter et al., 2004). Comprehensive studies of interactions between microbe activity and plant nutrient can certainly contribute to making correct conclusions and quality solutions to increase manganese availability through the implementation of adequate agrotechnical measures such as inoculation of the Mn-reducing microorganisms in soils or similar.

As shown in Table 2, the concentration of total $\mathrm{Zn}$ and $\mathrm{Cu}$ in the examined soil plots did not exceed the maximum permissible value for agricultural soil prescribed by legislation in Bosnia and Herzegovina and ranged from 45.6 to 51.3 and from 25.2 to $31.8 \mathrm{mg} \mathrm{kg}^{-1}$, respectively. These ranges are considered typical for $\mathrm{Zn}$ and $\mathrm{Cu}$ in soils. Available forms for these elements in examined soils were very low, especially for $\mathrm{Zn}$, indicating that the chemical properties i.e. relatively high $\mathrm{pH}$ value and lower organic matter content of examined soils, are not favorable for $\mathrm{Zn}$ and $\mathrm{Cu}$ solubility and availability and consequently for their uptake by plant roots (Iratkar et al., 2014). An additional reason for the extremely low availability of $\mathrm{Zn}$ in examined soils could be potentially attributed to the interaction of $\mathrm{Zn}$ with $\mathrm{Fe}$ and $\mathrm{Mn}$ in soils, and these interactions in soils have been confirmed by numerous studies (Ghasemi-Fasaei and Ronaghi, 2008; Soltangheisi et al., 2014).

Plant genetic potential is also important for nutrients uptake, especially if the manganese subject of research (Blamey et al., 2015). Different plant species have different degrees of tolerance on excess Mn in soil. Sonneveld and Voogt (1975) rated lettuce and beans as sensitive, cucumber as less sensitive and tomato as tolerant to excess $\mathrm{Mn}$ in soils. Degree of tolerance of raspberry on excess $\mathrm{Mn}$ in soil have not yet been sufficiently investigated, so the main purpose of this study is to contribute to a better understanding the dynamics of $\mathrm{Mn}$ in soilraspberry system.

The mechanisms of Mn uptake, transport and accumulation in raspberry and generally in plant tissues are still poorly understood. It is known that Mn as many other ions enter the root either through the plasma mem- 
brane of the root cells (symplastic transport) or through the free space between cells (apoplastic transport), and that $\mathrm{Mn}$ can not pass through membranes without the aid of membrane transporter proteins (Rengel, 2000). These transporter proteins occur naturally in cell membranes and plants possess many transporters for Mn transport. The abundance and activity of each transporter varies with types of plant tissues, development stage of plant, and environmental conditions, making the mechanism of Mn uptake, transport and accumulation in plant even more complicated. For example, when a low Mn concentration is in the soil solution, Mn uptake usually requires a high-affinity transporter or vice-versa, low-affinity transporters are more useful when high concentrations of $\mathrm{Mn}$ are present in soil solution (Cailliatte et al., 2010).

Plants have developed many types of mechanisms for identifying and involving $\mathrm{Mn}$ and other nutrients into essential cellular processes, but also for blocking them if their presence is harmful to the plant. The general rule in plant nutrition is that the elements useful for essential cellular processes are transported in tissues where they are needed, whereas the elements toxic for plant are stored in places where they cause the least harm to essential cellular processes (Pinto et al., 2014). The fact is that there is a tendency for $\mathrm{Mn}$ to easily translocate form roots to the leaves, indicating that $\mathrm{Mn}$ is needed in higher amounts for physiological processes in the plant, especially for photosynthesis where the Mn playing an important role in water-splitting system of photosystem II. The results of the present study confirm that fact as well as the fact that the Mn mostly accumulates in leaves, then in roots, and much less in the stem and fruits of raspberry. These findings are consistent with other research on the topic (Dou et al., 2009; Lambers et al., 2015).

An interesting finding of this study was that the Mn concentration in raspberry fruit was lower than the average $\mathrm{Mn}$ concentration for raspberry reported by many scientists (Tešović and Dulić, 1989; Ekholm et al., 2007). It is obvious that the low accumulation of $\mathrm{Mn}$ in the fruits was related to the physical and chemical characteristics of the examined soil as well as the climate conditions of the examined region.

Sharma et al. (2004) noted that Mn availability increased with a high increase in organic matter content and moisture in soil surface and subsurface horizons. Our assumption is that the properties of the studied soil (Cambisol) characterized by the absence of organic matter and appreciable quantities of clay fractions, do not favor the formation of reducing conditions in soil, thus resulting in lower $\mathrm{Mn}$ availability in soil and consequently lower accumulation in the fruit.

Another interesting finding of this study was that the concentration of $\mathrm{Cu}$ was about threefold higher in the root than in other parts of raspberry, while the difference in distribution within the plant was lower for other examined elements. This observation leads to the conclusion that the $\mathrm{Cu}$ in higher concentrations in leaves and fruits may have adverse effects on plant growth and development, and therefore the plant tends to keep $\mathrm{Cu}$ in the root where it cannot to a large extent negatively affect essential cellular processes. Emamverdian et al. (2015) have reported that the difference between the accumulation in root and the leaves is even higher for hazardous heavy metals such as $\mathrm{Cd}, \mathrm{Cr}$, and $\mathrm{Pb}$. It is evident that the plants possess different mechanisms to prevent or reduce the transport of hazardous heavy metals from roots to the to the above-ground parts of plants. Some of these mechanisms are precipitation, binding of metals by strong ligands, changing the harmful forms of heavy metals to less toxic form by redox mechanisms, as well as export of heavy metals out of the cells and plants (Leitenmaier and Küpper, 2013).

\section{CONCLUSIONS}

The concentration of Mn available forms in the examined soils was low, resulting in a low degree of Mn uptake and accumulation in the raspberry plants, although the concentration of total $\mathrm{Mn}$ in soils was high compared to the average as well as the potential toxic value of $\mathrm{Mn}$ in soil. It is assumed that the chemical and physical properties of examined soils characterized by relatively high $\mathrm{pH}$ value and good ability to store root-zone air, contributed to them. From the point of view of Mn distribution within the plant, it is evident that the Mn mostly accumulates in leaves and roots of raspberry, and much less in the stem and fruits.

\section{REFERENCES}

Blamey, F. P. C., Hernandez-Soriano, M. C., Cheng, M., Tang, C., Paterson, D. J., Lombi, E., Wang, W. H., Scheckel, K. G., Kopittke, P. M. (2015). Synchrotron-based techniques shed light on mechanisms of plant sensitivity and tolerance to high manganese in the root environment. Plant Physiology, 169, 2006-2020. https://doi.org/10.1104/pp.15.00726

Bradl, H. (2004). Adsorption of heavy metal ions on soils and soils constituents. Journal of Colloid and Interface Science, 277(1), 1-18. http://doi.org/10.1016/j.jcis.2004.04.005

Cailliatte, R., Schikora, A., Briat, J. F., Mari, S., Curie, C. (2010). High-affinity manganese uptake by the metal transporter NRAMP1 is essential for Arabidopsis growth in low manganese conditions. The Plant Cell, 22(3), 904-917. http://doi. org/10.1105/tpc.109.073023

Dou, C. M., Fu, X. P., Chen, X. C., Shi, J. Y., Chen, Y. X. (2009). Accumulation and detoxification of manganese in hy- 
peraccumulator Phytolacca Americana. Plant Biology (Stuttgart), 11(5), 664-670. http://doi.org/10.1111/j.14388677.2008.00163.x

Dučić, T., Polle, A. (2005). Transport and detoxification of manganese and copper in plants. Brazilian Journal of Plant Physiology, 17(1), 103-112. http://doi.org/10.1590/S167704202005000100009

Dufey, I., Hakizimana, P., Draye, X., Lutts, S., Bertin, P. (2009). QTL mapping for biomass and physiological parameters linked to resistance mechanisms to ferrous iron toxicity in rice. Euphytica, 167, 143-160. http://doi.org/10.1007/ s10681-008-9870-7

Egnér, H., Riehm, H., Domingo, W. R. (1960). Investigations on the chemical soil analysis as a basis for assessing the soil nutrient status II. Chemical extraction methods for phosphorus and potassium determination. Kungliga Lantbrukshügskolans Annaler, 26, 199-215.

Ekholm, P., Reinivuo, H., Mattila, P., Pakkala, H., Koponen, J., Happonen, A., Hellström, J., Ovaskainen, M. L. (2007). Changes in the mineral and trace element contents of cereals, fruits and vegetables in Finland. Journal of Food Composition and Analysis, 20(6), 487 - 495. http://doi. org/10.1016/j.jfca.2007.02.007

Emamverdian, A., Ding, Y., Mokhberdoran, F., Xie, Y. (2015). Heavy Metal Stress and Some Mechanisms of Plant Defense Response. The Scientific World Journal, ID 756120, 18. https://doi.org/10.1155/2015/756120

Emsley, J. (2001). Nature's building blocks: An a-z guide to the elements. Oxford: Oxford University Press.

Esu, I. E. (1991). Detailed soil survey of National Horticultural Research Institute (NIHORT) Farm at Bunkure, Kano State, Nigeria. Zaria: Institute for Agricultural Research, Ahmad Bello University.

FAO. (2014). World reference base for soil resources. Retrieved from http://www.fao.org/3/i3794en/I3794en.pdf

FAO/WHO. (2001). Food Additives and Contaminants (ALINORM No. 01/12A: 1-289). Retrieved from www.fao. org/input/download/report/27/Al0112Ae.pdf

Ghasemi-Fasaei, R., Ronaghi, A. (2008). Interaction of Iron with Copper, Zinc, and Manganese in Wheat as Affected by Iron and Manganese in a Calcareous Soil. Journal of Plant Nutrition, 31(5), 839-848. http://doi. org/10.1080/01904160802043148

Grigorova, I. (2011). Studies and possibilities of low grade manganese ore beneficiation. 22nd World Mining Congress (pp. 593-598). Ankara: Aydoğdu Ofset.

Guest, C. A., Schulze, D. G., Thompson, I. A., Huber, D. M. (2002). Correlating manganese X-ray absorption near-edge structure spectra with extractable soil manganese. Soil Science Society of America Journal, 66, 1172-1181. http://doi. org/10.2136/sssaj2002.1172

Horst, W. J. (1988). The Physiology of Manganese Toxicity. In R. D. Graham, R. J. Hannam \& N. C. Uren, (Eds.), Manganese in Soils and Plants' (pp. 175-188) Adelaide: Proceedings of the International Symposium on 'Manganese in Soils and Plants, University of Adelaide, Waite Agricultural Research Institute. http://dx.doi.org/10.1007/978-94-009-2817-6_13

Husson, O. (2013). Redox potential (Eh) and $\mathrm{pH}$ as drivers of soil/plant/microorganism systems: a transdiscipli- nary overview pointing to integrative opportunities for agronomy. Plant and Soil, 362(1-2), 389-417. http://doi. org/10.1007/s11104-012-1429-7

International Organization for Standardization. (1995). Soil quality - Extraction of trace elements soluble in aqua regia (ISO Standard No. 11466). Retrieved from https://www.iso. org/standard/19418.html

International Organization for Standardization. (1998). Soil quality - Determination of organic carbon in soil by sulfochromic oxidation (ISO Standard No. 14235). Retrieved from https://www.iso.org/standard/23140.html

International Organization for Standardization. (1998). Soil quality - Determination of cadmium, chromium, cobalt, copper, lead, manganese, nickel and zinc-Flame and electrothermal atomic absorption spectrometric methods (ISO Standard No. 11047). Retrieved from https://www.iso.org/ standard/24010.html

International Organization for Standardization. (2005). Soil quality - Determination of pH (ISO Standard No. 10390). Retrieved from https://www.iso.org/standard/40879.html

Iratkar, A. G., Giri, J. D., Kadam, M. M., Giri, J. N., Dabhade, M. B. (2014). Distribution of DTPA extractable micronutrients and their relationship with soil properties in soil of Parsori watershed of Nagpur district of Maharashtra. Asian Journal of Soil Science, 9, 297-299.

Kabata-Pendias, A., Pendias, H. (1999). Biogeochemistry of Trace Elements. Warsaw: Polish Scientific Publishing Company.

Kabata-Pendias, A., Pendias, H. (2001). Trace Elements in Soils and Plants. Boca Raton, Fla., London: CRC Press.

Kastori, R., Petrović N., Arsenijević-Maksimović, I. (1997). Heavy metals in the environment. Novi Sad: University of Novi Sad, Faculty of Agriculture.

Khabaz-Saberi, H., Rengel, Z. (2010). Aluminum, manganese, and iron tolerance improves performance of wheat genotypes in waterlogged acidic soils. Journal of Plant Nutrition and Soil Science, 173, 461-468. http://doi.org/10.1002/ jpln.200900316

Lambers, H., Hayes, P. E., Laliberte, E., Oliveira, R. S., Turner, B. L. (2015). Leaf manganese accumulation and phosphorusacquisition efficiency. Trends in Plant Science 20(2), 83-90. http://doi.org/10.1016/j.tplants.2014.10.007

Lei, Y., Korpelainen, H., Li, C. (2007). Physiological and biochemical responses to high $\mathrm{Mn}$ concentrations in two contrasting Populus cathayana populations. Chemosphere, 68(4), 686-694. http://doi.org/10.1016/j.chemosphere.2007.01.066

Leitenmaier, B., Küpper, H. (2013). Compartmentation and complexation of metals in hyperaccumulator plants. Frontiers in Plant Science, 4, 374. http://doi.org/10.3389/ fpls.2013.00374

Li, Z., McLaren, R. G., Metherell A. K. (1999). The effects of soil manganese status on the bioavailability of soil cobalt for pasture uptake in New Zealand Soils. Proceedings of the New Zealand Grassland Association, 61, 133-137.

Lindsay, W. L., Cox, F. R. (1985). Micronutrient soil testing for the tropics. Fertilizer Research, 7(1-3), 169-200. http://doi. org/10.1007/978-94-009-5055-9_7

Lindsay, W. L., Norvell, W. A. (1978). Development of a DTPA 
Soil Test for Zinc, Iron, Manganese, and Copper. Soil Science Society of America Journal, 42(3), 421-428. http://doi. org/10.2136/sssaj1978.03615995004200030009x

Lisjak, M., Špoljarević, M., Agić, D., Andrić, L. (2009). Laboratory Exercises in Plant Physiology. Osijek: Josip Juraj Strossmayer University of Osijek, Faculty of Agriculture.

Marschner, P., Crowley, D., Rengel, Z. (2011). Rhizosphere interactions between microorganisms and plants govern iron and phosphorus acquisition along the root axis - model and research methods. Soil Biology and Biochemistry, 43, 883894. http://doi.org/10.1016/j.soilbio.2011.01.005

Millaleo, R., Reyes-Diaz, M., Ivanov, A. G., Mora, M. L., Alberdi, M. (2010). Manganese as essential and toxic element for plants: transport, accumulation and resistance mechanisms. Journal of Soil Science and Plant Nutrition 10(4), 470-481. http://doi.org/10.4067/S0718-95162010000200008

Mousavi, S. R., Shahsavari, M., Rezaei, M. (2011). A General Overview on Manganese (Mn) Importance for Crops Production. Australian Journal of Basic and Applied Sciences, 5(9), 1799-1803.

Nunes, J. R., Ramos-Miras, J., Lopez-Piñeiro, A., Loures, L., Gil, C., Coelho, J., Loures, A. (2014). Concentrations of available heavy metals in Mediterranean agricultural soils and the relation with some soil selected properties: A case study in typical Mediterranean soils. Sustainability, 6, 9124-9138. http://doi.org/10.3390/su6129124

Official Gazette of FBiH. (2009). Rulebook on determination of allowable quantities of harmful and hazardous substances in soils of Federation of Bosnia and Herzegovina and methods for their testing (No 72/09). Retrieved from http://www. fuzip.gov.ba

Pais, I., Jones J. B. (1997). The Handbook of Trace Elements. Boca Raton, Fla., London: CRC Press.

Pinto, E., Aguiar, A., A., R., M., Ferreira, I. M. P. L. V. O. (2014). Influence of Soil Chemistry and Plant Physiology in the Phytoremediation of $\mathrm{Cu}, \mathrm{Mn}$, and $\mathrm{Zn}$. Critical Reviews in Plant Sciences, 33(5), 351-373. http://doi.org/10.1080/0735 2689.2014.885729

Podlešáková E., Němeček, J., Vácha R. (2002). Critical values of trace elements in soils from the viewpoint of the transfer pathway soil - Plant. Rostlinna Vyroba 48(5), 193-202. http://doi.org/10.17221/4224-PSE

Porter, G. S., Bajita-Locke, J. B., Hue, N. V., Strand, D. (2004). Manganese solubility and phytotoxicity affected by soil moisture, oxygen levels, and green manure additions. Communications in Soil Science and Plant Analysis, 35, 99-116. http://doi.org/10.1081/CSS-120027637

Redžić, S., Sijarić, G., Muhić-Šarac, T., Pehić, E., Hrnjica, D. (2014). Distribution and bioavailability of manganese in soil in the vicinity of the 'Bužim' abandoned mine. Geologia Croatica, 67(1), 45-58. http://doi.org/10.4154/GC.2014.04

Rengel, Z. (2000). Uptake and transport of manganese in plants. In: A. Sigel \& H. Sigel (Eds.), Metal Ions in Biological Systems (pp. 57-87). New York, NY: Marcel Dekker

Rengel, Z. (2015). Availability of Mn, Zn and Fe in the rhizosphere. Journal of soil science and plant nutrition, 15(2), 397409. http://doi.org/10.4067/S0718-95162015005000036

Scăeţeanu, G. V., Ilie, l., Călin, C. (2013). An Overview on Manganese in Nature. American Chemical Science Journal, 3(3), 247-263.

Sharma, B. D., Mukhopadhyay, S. S., Sidhu, P. S., Katyal, J. C. (2000). Pedospheric attributes in distribution of total and DTPA-extractable $\mathrm{Zn}, \mathrm{Cu}, \mathrm{Mn}$ and $\mathrm{Fe}$ in Indo-Gangetic plains. Geoderma, 96, 131-151. http://doi.org/10.1016/ S0016-7061(00)00008-2

Sillanpää, M. (1982). Micronutrients and the nutrient status of soils: a global study. FAO, Rome: FAO Soils Bulletin.

Soltangheisi, A., Rahman, Z. A., Ishak, C. F., Musa H. M., Zakikhani, H. (2014). Interaction Effects of Zinc and Manganese on Growth, Uptake Response and Chlorophyll Content of Sweet Corn (Zea mays var. saccharata). Asian Journal of Plant Sciences, 13, 26-33. http://doi.org/10.3923/ ajps.2014.26.33

Sonneveld, C., Voogt, S. J. (1975). Studies on the manganese uptake of lettuce on steam sterilized glasshouse soils. Plant Soil, 42, 49-64.

Sparrow, L. A., Uren, N. C. (2014). Manganese oxidation and reduction in soils: effects of temperature, water potential, $\mathrm{pH}$ and their interactions. Soil Research, 52, 483-494. http:// doi.org/10.1071/SR13159

Tešović, Z., Dulić, I. (1989). Microelement levels in the fruits of red raspberry (Rubus idaeus L.) cultivars and selections. Acta Horticulturae. 262, 327-332. http://doi.org/10.17660/ ActaHortic.1989.262.47

Trierweiler, J. E., Lindsay, W. L. (1969). EDTA-ammonium carbonate soil test for zinc. Soil Science Society of America Proceedings, 39, 49-54.

Violante, A., Cozzolino, A., Perelomov, V., Caporale, A.G., Pigna, M. (2010). Mobility and bioavailability of heavy metals and metalloids in soil environments. Journal of Soil Science and Plant Nutrition, 10(3), 268-292. http://doi.org/10.4067/ S0718-95162010000100005

Vukadinović, V., Vukadinović, V. (2011). Plant nutrition. Osijek: Josip Juraj Strossmayer University of Osijek, Faculty of Agriculture.

Wang, Y., Jin, S., Lv, Y., Zhang Y., Su H. (2017). Hydrometallurgical Process and Kinetics of Leaching Manganese from Semi-Oxidized Manganese Ores with Sucrose. Minerals, 7, 27. https://doi.org/10.3390/min7020027 